\title{
Comparative Appraisal of Metro Stations in Delhi Using Data Envelopment Analysis in a Multimodal Context
}

\author{
Mansha Swami, Manoranjan Parida \\ IIT-Roorkee
}

\begin{abstract}
Urban public transit is a critical component for sustainable urban development and is crucial to multisector expansion of a developing economy. Continuous monitoring of infrastructure performance and assessment of its effectiveness are required to continually improve service quality. The urban agglomeration of Delhi, India, was studied for the efficacy of its multimodal urban public transit system. The toolkit used was Data Envelopment Analysis (DEA), a linear optimization technique that estimates relative efficiencies of its decision making units (DMUs) for a multitude of inputs and outputs. The study area includes the Red and Yellow lines of the Delhi Metro network. Commuterbased questionnaires were used to collect 1,328 valid responses about demographic, travel time, and quality perception parameters, which were analyzed, and relative rankings of the DMUs were evaluated. The efficiency was analyzed according to the Red and Yellow lines divided into seven corridor segments and individual stations. Results revealed efficiency scores and inefficiency slacks for which improvement strategies are proposed.
\end{abstract}

Keywords: Data Envelopment Analysis, Decision Making Units, DMU, slack values, projected values, multimodal transit, efficiency evaluation

\section{Introduction}

The urbanscape of developing countries is struggling with the ever-emerging demands of growing population and infrastructure. With economic growth, the responsibility of a city increases in delivery of services to its citizens. The deterioration in Indian public transport is more prevalent in metropolitan cities, in which the increase in the number of motorized vehicles is huge. Delhi constitutes nearly $7 \%$ of all motor vehicles in India but accommodates only $1.4 \%$ of the Indian population (Singh 2005). The population of Delhi is approximately 16.8 million (Census of India 2011). The multimodal urban transit 
system in Delhi was studied in a comprehensive manner in this paper, and the Delhi Metro, the line haul mode in this system, was the emphasis in this study.

A multimodal urban transit system essentially comprises four main elements: access leg, egress leg, line haul leg, and transfer stages. Multimodal transportation clearly identifies the stage-based nature of public transport (Krygsman et al. 2001). A terminal plays a vital role in a trip. When two or more modes are used in a trip in which at least one mode is a conventional public transport mode, the trip is called a multimodal trip. The structure of a multimodal trip is as illustrated in Figure 1.

FIGURE 1.
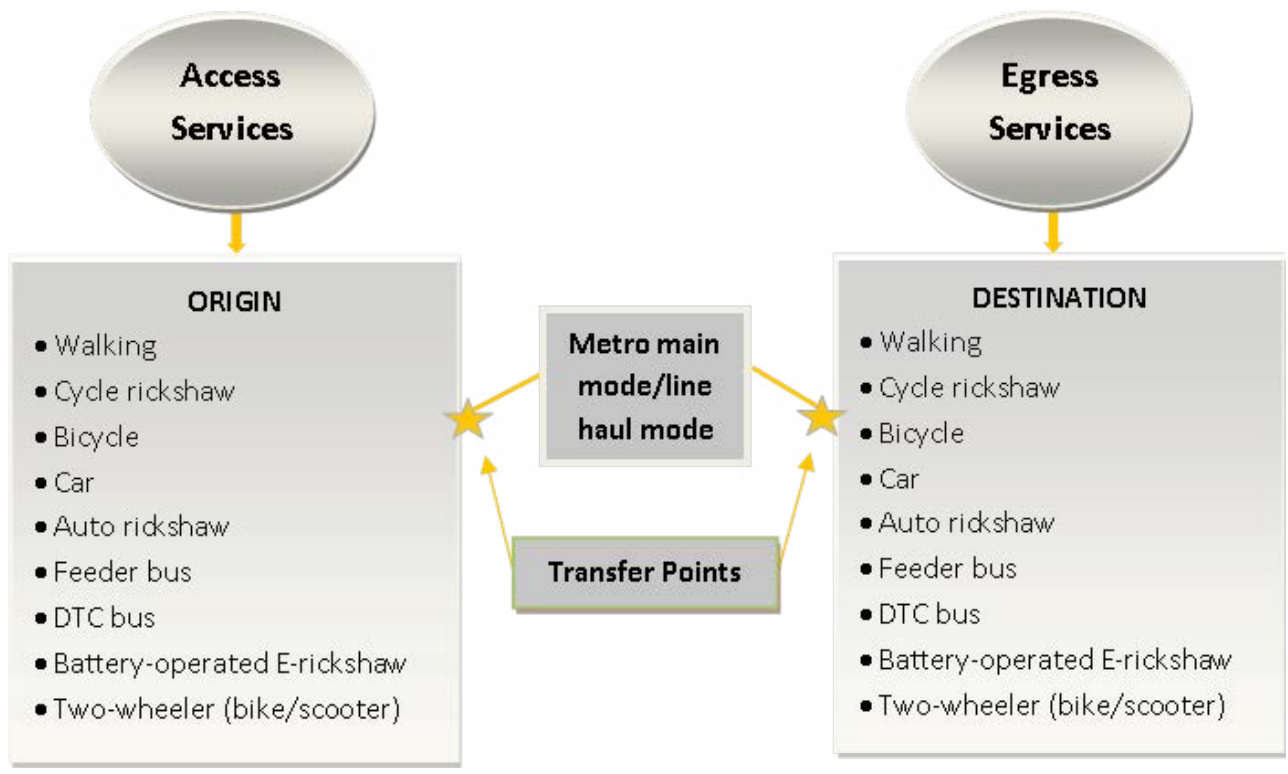

In most cases, egress has a disadvantage over the availability of personal modes at the destination end. Transfer among different transportation modes may take place in a smaller area to enhance transfer efficiency, as time and cost consumed will become less (Sun et al. 2007). Sun et al. (2007) conducted a study in which transit terminal assessment was carried out under the influence of parameters such as transfer area, operating expense, number of staff, capacity of bus, total number of transfer passengers, transfer safety, and transfer time taken. In this study, the importance of carrying out a multimodal efficiency analysis using a metro station as a focal point was more consolidated.

Waiting times are a component of travel time delay along with transfer times in most multimodal trips. According to van Oort et al. (2009), if the services of a transit mode are being performed adequately, then waiting time is equal to half the headway time. This applies to short headways, and, in the case of longer headways, the passenger is likely to arrive closer to the scheduled time. Also, they discussed that vehicles and drivers of public transit units, owing to their dynamic characteristics, cause delays and congestion, thereby reducing service regularity, which the traveler perceives as a longer waiting time compared to the expected times. 
The attractiveness of transfers may not be a hurdle if transfers are easy and provide access to the entire public transport network (Maxwell 2003). Also, better integrating the costs of transfers will result in increased attractiveness (Hidalgo 2009). Comfort and safety are other attributes that should influence passenger decisions (Atkins 1990; Kumar et al. 2011; Guo and Wilson 2011).

In the present scenario for a city such as Delhi, instead of increasing the number of modes, the city needs to manage the current modes in congruence with each other to yield better system efficiency and patronage. Two major aspects that need to be understood before starting an evaluation or assessment study on a urban public transport system are determining the factors that dissuade and influence passengers traveling on public transport (Naveen Eluru et al. 2012). Attributes such as travel time, waiting time, number of transfers, walking time, income, and gender play key roles in this selection. In a factor analysis study done on the attributes of importance, results yielded that information services play a key role. The other important factor was street service, which includes transfer convenience, bus frequency, level of service, reliability of service, and well-planned routes (Sharfuddin et al. 2000).

Another study proposed the definitive difference between planned and unplanned transfers, including five attributes-network integration, integrated physical connection of transfers, integrated time transfer, information integration, and fare ticket integration (Chowdhury and Ceder 2013). It was observed from this study that commuters had more willingness to use transfer-based routes when these five attributes are better aligned to the planned alignment. Smart et al. (2009) studied transit stop performance from the perspective of the operating agency instead of the user. When a transit operating agency has full control of the premises of a transit station or stop, it is more likely to better influence the attributes concerning operational requirements (Vuchic and Kikuchi 1974).

\section{Study Methodolgy}

\section{Identification of Study Area}

Delhi, the capital of India, has many public transportation modes. The Delhi Metro is a very widely distributed network with an extensive multimodal urban public transit system. The route map of the Delhi Metro is shown in Figure 2. 


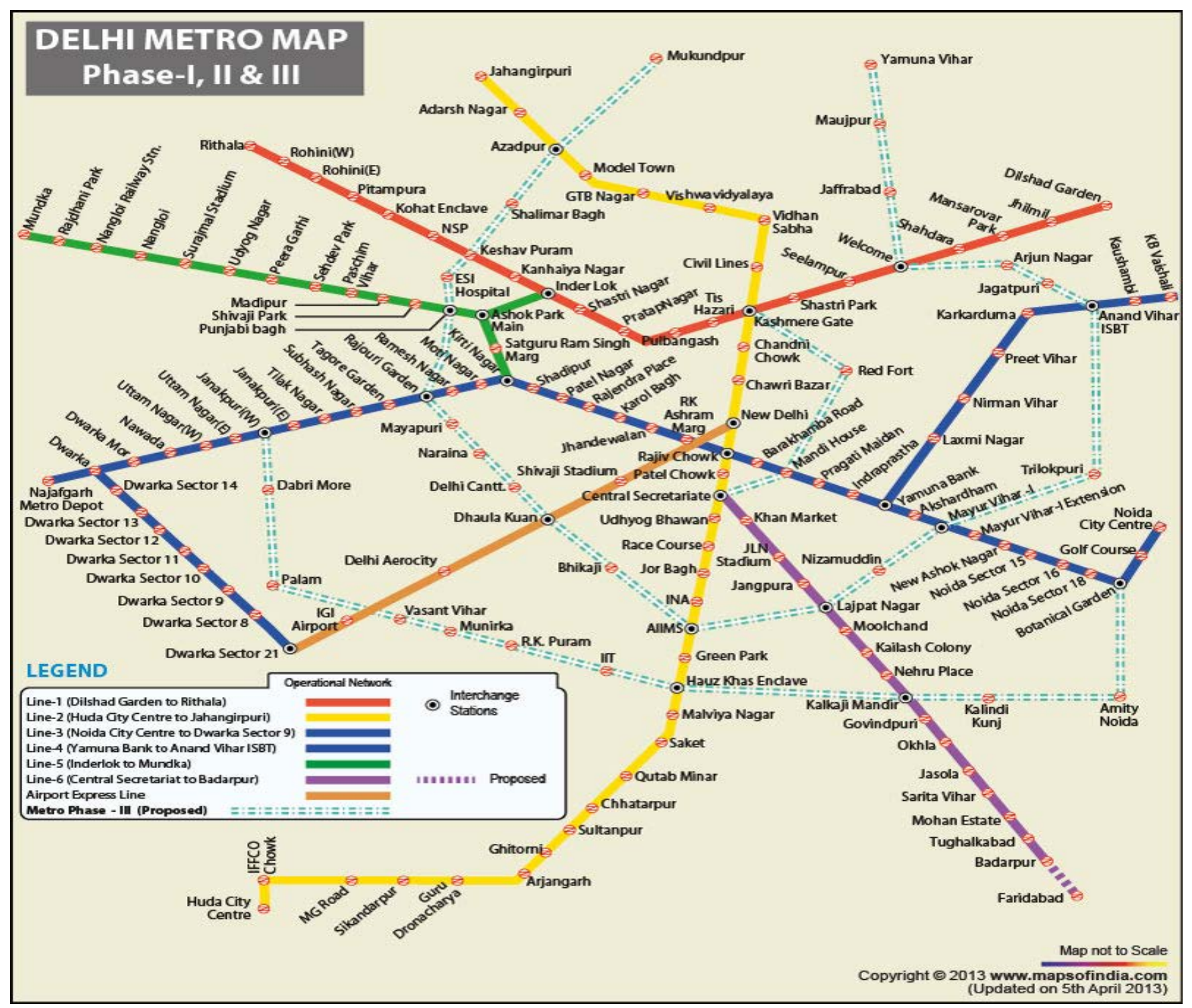

FIGURE 2. Map of Delhi Metro routes

The Delhi Metro was launched in 2002 with two successfully-operating phases. With Phase 3 in the works, and Phase 4 to begin operating in the next decade, the Delhi Metro will be more extensive and distributed than ever, which will increase the connectivity of the city. To identify best practices for replication in the upcoming phases, this study assessed the proximity and overall interconnectivity of the metropolitan area by conducting a comprehensive evaluation of various resource units and performance indicators of the existing system. The study methodology is shown in Figure 3. 
FIGURE 3. Study methodology flowchart
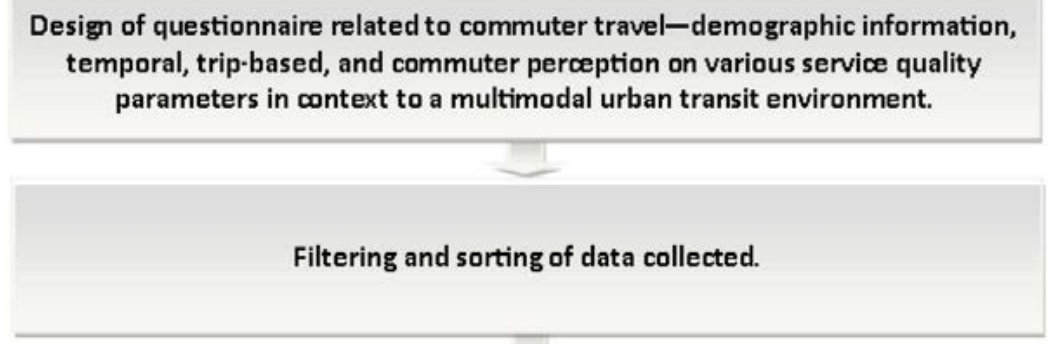

Identification of various performance units and their respective resource units for assembly of input/output sets for analysis in DEA.

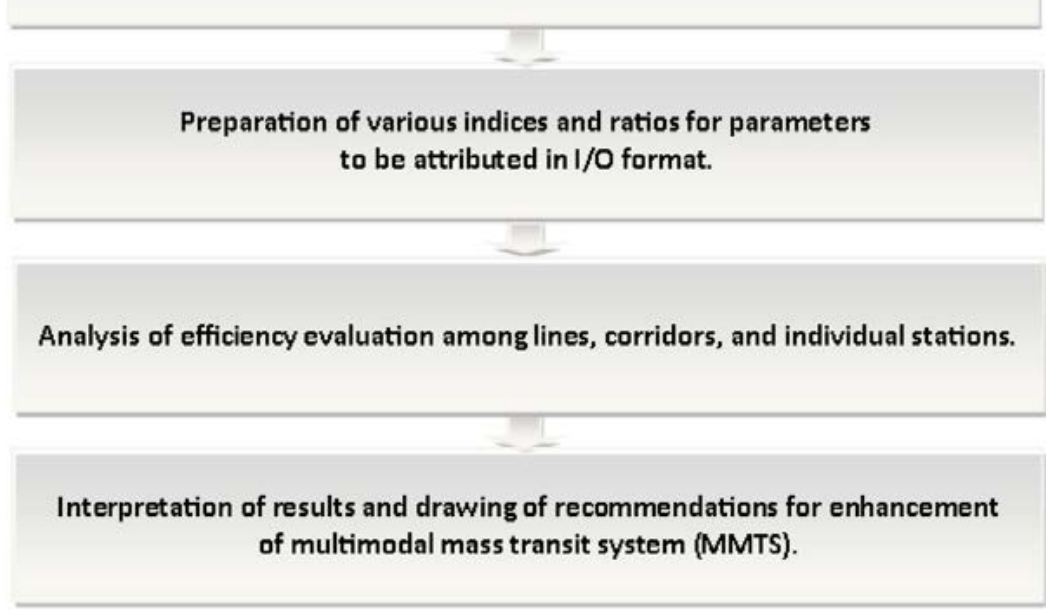

\section{Concept of DEA-based Efficiency}

Data Envelopment Analysis (DEA) is a performance measurement technique that uses a comparative analysis methodology. It was developed in 1978 by Charnes, Cooper and Rhodes to aid the evaluation of various organizations. Karlaftis (2003) used it to conduct an efficiency analysis of transit companies, and Zhenlin et al. (2012) conducted a comprehensive efficiency evaluation of the Beijing intelligent traffic management system based on super-DEA that used 15 inputs and 23 outputs for 10 Decision Making Units (DMUs) for a macro level study correlating the influence of various urban transport indicators.

Epstein and Henderson (1989) concluded that all variables that are included in the model have an equal opportunity to influence the calculated efficiency. Here, DEA has advantages over traditional efficiency calculations. The efficiencies of public transportation subunits were calculated for the Chicago Transit Authority (Barnum et al. 2007), and Saxena Punitha et al. (2010) conducted a study to measure the efficiencies of Indian public road transit using DEA with input variables such as fleet size, total staff, and fuel consumption and output parameters such as passenger kilometers and seat kilometers for 26 DMUs.

DEA compares different DMUs, which are often the resource units for a system. In the present study, DMUs were the metro stations of the Delhi Metro system. An output unit is usually a performance attribute to be judged, and the inputs and outputs are 
finalized on the basis of correlation between the two in terms of the impact of inputs on outputs. Then, their comparative efficiencies are compared, and best practice units are identified. Also, DEA identifies slacks in the resource and output units and determines their projected values. The slack values for metro station performance can be helpful in determining the cause of their poor or good performance.

In the DEA model, the concept of efficiency is technical efficiency, which is the basic concept of relative efficiency that is determined through comparison with the most efficient unit. The relative efficiency $(\eta)$ typically is represented in the mathematical form in Equation 1. In this case, the unit is the Metro station and, in place of weight of inputs, we used the values of the input parameters. $y_{r j}$ and $X_{i j}$ are the projected values obtained for various Metro stations from the analysis for different sets.

$$
\begin{aligned}
& \boldsymbol{n}_{\boldsymbol{j}}=\frac{\sum_{\boldsymbol{r}} u_{\boldsymbol{r}} \boldsymbol{y}_{\boldsymbol{r} \boldsymbol{j}}}{\sum_{\boldsymbol{i}} \boldsymbol{v}_{\boldsymbol{i}} \boldsymbol{x}_{\boldsymbol{i} \boldsymbol{j}_{\boldsymbol{j}}}} \\
& \eta_{j}=\text { relative efficiency of unit } \mathrm{j} \\
& v_{i}=\text { weight of Input } \mathrm{i} \\
& u_{r}=\text { weight of Output } \mathrm{r} \\
& y_{r j}=\text { the quantity of Output } \mathrm{r} \text { for unit } \mathrm{j} \\
& x_{i j}=\text { the quantity of Input } \mathrm{i} \text { for unit } \mathrm{j} \\
& j=1,2,3 \ldots \mathrm{n} \\
& n=\text { number of units }
\end{aligned}
$$

This technique can be used to assess the existing system and further enhance the service quality by identifying the gaps and is based on linear programming methodology. The ratios are apt for calculation of efficiency in the case of a single input and output. However, for multiple inputs and/or outputs, scenario relative weights of each of the resource and performance entities need to be considered.

\section{DEA Software}

A multi-stage DEA model was used, which is capable of handling a multitude of inputs and outputs. In the present analysis, however, only multiple inputs were considered. The outputs in each of the six objective sets were single outputs. The number of inputs varied for each set of objectives.

Also, the multi-stage DEA analysis was done in output-oriented mode, which focuses on expansion of output to achieve scores. This study used constant returns to scale (CRS), meaning that outputs were modified in the same proportion as inputs. In this study, infrastructural components of the system were constant even if the operational parameters or the outputs were changed; therefore, the constant returns to scale are preferred here.

The DEAP software allowed for the creation of lists of inputs and outputs of Metro stations in Notepad and then was incorporated into the model requirements separately in an instruction file format (.ins) (see Figure 4). The result can be obtained in a Notepad file that can be conveniently converted to Excel. 
FIGURE 4.

Illustration of.ins file in DEAP software

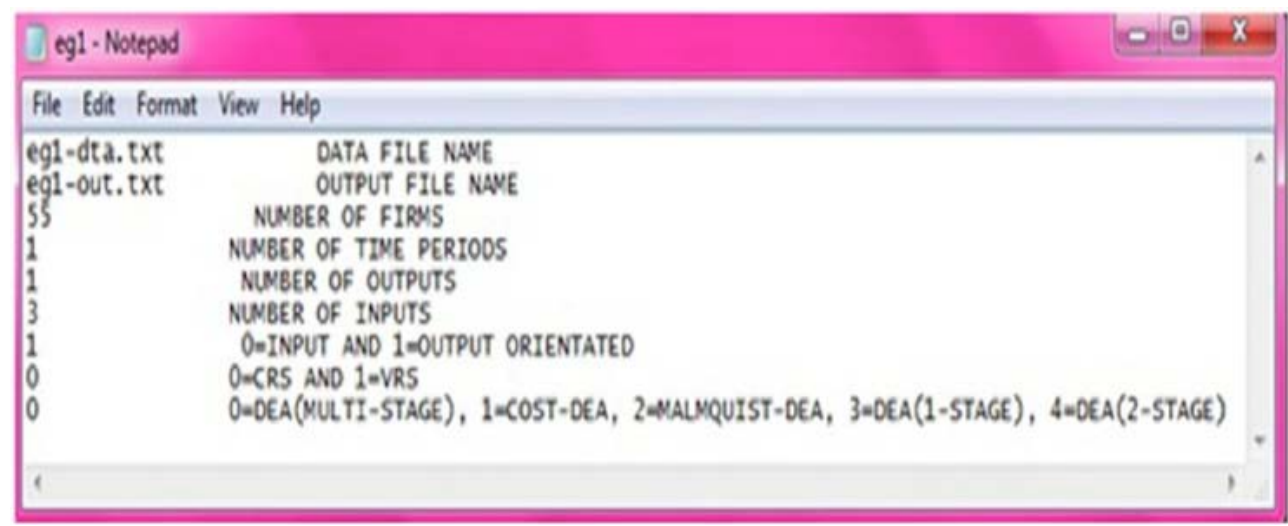

\section{DEA Inputs and Outputs}

As in a previous study in Cosenza, Italy (Eboli et al. 2009), the parameters considered for the performance study included route characteristics, service characteristics, service reliability, comfort, cleanliness, fare, information, safety and security, customer service, personnel, and environmental factors. The definitions of parameters used in the framing of the inputs and their respective outputs in this study are shown in Table 1. The parameters Interconnectivity Convenience (Ic) and Service Time Ratio (STR) were conceptualized specifically for this analysis.

TABLE 1. Definitions of Parameters Used in DEA

\begin{tabular}{|c|c|c|c|}
\hline \multicolumn{2}{|r|}{ Name } & Description & Ratio \\
\hline LOS & Level of Service & $\begin{array}{l}\text { Ratio of OVTT to IVTT; the larger the ratio, the less attractive the } \\
\text { public transport. }\end{array}$ & $1.2-5$ (most trips) \\
\hline IR & $\begin{array}{l}\text { Interconnectivity } \\
\text { Ratio }\end{array}$ & Ratio of access + egress time to total trip travel time. & $\begin{array}{l}0-1 ; \text { most multimodal trips }= \\
0.2-0.5\end{array}$ \\
\hline IVTT & In-Vehicle Travel Time & Time spent in main public transport mode in line-haul stage. & \\
\hline$I_{c}$ & $\begin{array}{l}\text { Interconnectivity } \\
\text { Convenience }\end{array}$ & Percentage of IVTT spent in access + egress, expressed in \%. & $\mathrm{I}_{\mathrm{c}}=\frac{(\text { ACCESS }+ \text { EGRESS })}{I V T T} * 100$ \\
\hline PWI & $\begin{array}{l}\text { Passenger Waiting } \\
\text { Index }\end{array}$ & $\begin{array}{l}\text { Ratio of mean passenger waiting time to frequency of transport } \\
\text { service. Close to } 0 \text { is not possible. }\end{array}$ & Fixed between $0-1$ \\
\hline RI & Running Index & $\begin{array}{l}\text { Ratio of total service time (IVTT+OVTT) to total travel time. As RI } \\
\text { increases, system efficiency decreases.For passenger satisfaction, } \\
\text { value can be fixed between } 0.15 \text { and } 0.75 \text {. }\end{array}$ & Fixed between $0-1$ \\
\hline OVTT & $\begin{array}{l}\text { Out-of-Vehicle Travel } \\
\text { Time }\end{array}$ & $\begin{array}{l}\text { Time spent traveling in other modes for access/egress apart from } \\
\text { main line-haul mode. }\end{array}$ & \\
\hline TTR & Travel Time Ratio & $\begin{array}{l}\text { Ratio of travel time by public transport to travel time by personal } \\
\text { mode such as cars between a particular origin and destination }\end{array}$ & $1-5$ (most trips) \\
\hline TTT & Total Travel Time & Sum of IVTT, OVTT, transfer time, and wait time. & \\
\hline \multirow[t]{2}{*}{ STR } & Service Time Ratio & Ratio of penalty time (wait time + transfer time) to TTT. & $0-0.5$ (most trips) \\
\hline & Penalty & Sum of waiting time and transfer time. & \\
\hline
\end{tabular}


The parameters in Table 1 were assimilated into interrelated groups to form sets with multiple inputs and single outputs. The interrelationship between outputs and inputs was based on a cause-effect relationship. For example, in Set 1, the ridership on a line is likely to be affected by operation timing, roundtrip distance coverage, and number of stations, which indicates how many areas on the route have access to the line. In the current study, the sections were limited to six combinations. These sets were then analyzed using DEAP software to determine the relative efficiencies of the DMUs, which, in four of the six cases, were corridors of the Yellow and Red lines separated into seven parts; in two sets, the DMUs were the individual stations of the Red and Yellow lines. Table 2 shows the inputs and outputs in their respective sets.

\begin{tabular}{|c|c|c|c|c|c|}
\hline \multirow{19}{*}{$\begin{array}{r}\text { TABLE } 2 . \\
\text { Input and Output Sets } \\
\text { Used in DEA }\end{array}$} & No. & Name & Inputs & Units & Output \\
\hline & \multirow{3}{*}{1} & \multirow{3}{*}{$\begin{array}{l}\text { Line } \\
\text { Performance }\end{array}$} & Operation Time & $\min$ & \multirow{3}{*}{ Ridership on Line } \\
\hline & & & Round Trip Distance & k & \\
\hline & & & Number of Metro Stations in Line & $\#$ & \\
\hline & \multirow{3}{*}{2} & \multirow{3}{*}{$\begin{array}{l}\text { Operational } \\
\text { Efficiency of } \\
\text { Line }\end{array}$} & Operating Speed & kmph & \multirow{3}{*}{$\begin{array}{l}\text { Interconnectivity } \\
\text { Ratio (IR) }\end{array}$} \\
\hline & & & Frequency & $\min$ & \\
\hline & & & Access/Egress Time & $\min$ & \\
\hline & \multirow{4}{*}{3} & \multirow{4}{*}{$\begin{array}{l}\text { Spatial } \\
\text { Efficiency of } \\
\text { Line }\end{array}$} & Total Travel Time (TTT) & $\min$ & \multirow{4}{*}{$\begin{array}{l}\text { Interconnectivity } \\
\text { Convenience }\left(I_{c}\right)\end{array}$} \\
\hline & & & Customer Perception Score on Access and Egress & index \# & \\
\hline & & & Availability of Feeder in Area & \# & \\
\hline & & & Travel Time Ratio (TTR) & ratio & \\
\hline & \multirow{3}{*}{4} & \multirow{3}{*}{$\begin{array}{l}\text { Proximal } \\
\text { Efficiency }\end{array}$} & Total Transfer Time (TTRT) & $\min$ & \multirow{3}{*}{$\begin{array}{l}\text { Access+Egress } \\
\text { Time }\end{array}$} \\
\hline & & & Total Wait Time (TWT) & $\min$ & \\
\hline & & & In-Vehicle Travel Time (IVTT) & $\min$ & \\
\hline & \multirow[b]{2}{*}{5} & \multirow{2}{*}{$\begin{array}{l}\text { Information } \\
\text { and Safety } \\
\text { Efficiency }\end{array}$} & Security Score & index \# & \multirow{2}{*}{$\begin{array}{l}\text { Overall Customer } \\
\text { Perception of } \\
\text { Multimodal } \\
\text { Transport System } \\
\end{array}$} \\
\hline & & & Information Score & index \# & \\
\hline & \multirow{3}{*}{6} & \multirow{3}{*}{$\begin{array}{l}\text { Multimodal } \\
\text { Efficiency }\end{array}$} & Passenger Waiting Index (PWI) & ratio & \multirow{3}{*}{$\begin{array}{l}\text { Level of Service } \\
\text { (LOS) }\end{array}$} \\
\hline & & & Running Index (RI) & ratio & \\
\hline & & & Interconnectivity Ratio (IR) & ratio & \\
\hline
\end{tabular}

Line performance gives the comparative performances of the seven segments on a broader perspective. Operational efficiency of the line takes into account operational performance of the segments. Spatial efficiency considers the connectivity in a spatial context. Proximal efficiency compares catchment area access and egress availability. Information and safety efficiency evaluates facilities for safety and the quality of information provided to passengers. Multimodal efficiency checks the performance in context and coordination with the other modes of the urban public transportation system that a passenger uses in his/her journey from door of origin to door of destination. 


\section{DEA Results and Interpretations}

The six possible combinations of analysis are discussed below.

\section{Delhi Metro Corridor Performance}

The input and output data for this evaluation were collected from Delhi Metro Rail Corporation (DMRC). The data and results of this set are shown in the Tables 3 and 4.

TABLE 3.

Inputs and Outputs for

Corridor Performance of Delhi Metro

\begin{tabular}{|l|c|c|c|c|c|}
\hline \multirow{2}{*}{ Delhi Metro Corridors } & \multirow{2}{*}{ Line } & $\begin{array}{c}\text { Operation } \\
\text { Time } \\
\text { (hrs) }\end{array}$ & $\begin{array}{c}\text { Round Trip } \\
\text { Distance } \\
(\mathbf{k m})\end{array}$ & $\begin{array}{c}\text { Number } \\
\text { of Metro } \\
\text { Stations }\end{array}$ & $\begin{array}{c}\text { Ridership on } \\
\text { Line } \\
\text { (August 2014) }\end{array}$ \\
\cline { 3 - 6 } & Input 1 & Input 2 & Input 3 & Output \\
\hline Jahangirpuri to Kashmere Gate & Yellow & 17.5 & 21.8 & 9 & 288,975 \\
\hline Chandni Chowk to Central Secretariat & Yellow & 17.5 & 13.6 & 6 & 276,789 \\
\hline Udyog Bhawan to Saket & Yellow & 17.5 & 24.6 & 9 & 205,434 \\
\hline Qutub Minar to Huda City Center & Yellow & 17.5 & 29.0 & 10 & 191,230 \\
\hline Rithala to Kanhaiya Nagar & Red & 18 & 17.2 & 8 & 153,429 \\
\hline Inderlok to Kashmere Gate & Red & 18 & 12.6 & 6 & 103,110 \\
\hline Shastri Park to Dilshad Garden & Red & 18 & 15.0 & 7 & 125,649 \\
\hline
\end{tabular}

As shown in Table 4, the most technically-efficient corridors among the seven are the Jahangirpuri to Kashmere Gate corridor and Chandni Chowk to Central Secretariat (column 2). Both of these corridors are integral parts of the Yellow line. Results of the overall line performance efficiency test revealed the presence of negative slacks (column 6) for several input parameters in projected values, indicating that these corridors could improve their services in relevant domains. Figure 6 is a graphical comparison of the efficiency scores and ranks of corridor performance.

TABLE 4. Summary of Corridor Performance Efficiency

\begin{tabular}{|c|c|c|c|c|c|c|c|c|c|}
\hline Line & $\begin{array}{c}\text { Delhi Metro } \\
\text { Corridors } \\
{[1]}\end{array}$ & $\begin{array}{l}\text { Efficiency } \\
\text { Score } \\
\text { [2] }\end{array}$ & $\begin{array}{c}\text { Rank } \\
\text { [3] }\end{array}$ & $\begin{array}{c}\text { Original Value } \\
\text { of Outputs } \\
\text { [4] }\end{array}$ & $\begin{array}{c}\text { Projected Value } \\
\text { Of Output } \\
\text { [5] }\end{array}$ & \multicolumn{2}{|c|}{$\begin{array}{c}\text { Slack Value } \\
\text { of Inputs } \\
{[6]}\end{array}$} & $\begin{array}{c}\text { Projected Value } \\
\text { of Inputs } \\
\text { [7] }\end{array}$ & $\begin{array}{c}\text { Difference between } \\
{[4] \&[5]=} \\
{[8]}\end{array}$ \\
\hline \multirow{3}{*}{ Yellow } & \multirow{3}{*}{$\begin{array}{l}\text { Jahangirpuri to } \\
\text { Kashmere Gate }\end{array}$} & \multirow{3}{*}{1.000} & \multirow{3}{*}{1} & \multirow{3}{*}{288,975} & \multirow{3}{*}{$288,975.000$} & 1 & 0.0 & 17.500 & \multirow{3}{*}{0.000} \\
\hline & & & & & & 2 & 0.0 & 21.800 & \\
\hline & & & & & & 3 & 0.0 & 9.000 & \\
\hline \multirow{3}{*}{ Yellow } & \multirow{3}{*}{$\begin{array}{l}\text { Chandni Chowk } \\
\text { to Central } \\
\text { Secretariat }\end{array}$} & \multirow{3}{*}{1.000} & \multirow{3}{*}{2} & \multirow{3}{*}{276,789} & \multirow{3}{*}{$276,789.000$} & 1 & 0.0 & 17.500 & \multirow{3}{*}{0.000} \\
\hline & & & & & & 2 & 0.0 & 13.600 & \\
\hline & & & & & & 3 & 0.0 & 6.000 & \\
\hline \multirow{3}{*}{ Yellow } & \multirow{3}{*}{$\begin{array}{l}\text { Udyog Bhawan } \\
\text { to Saket }\end{array}$} & \multirow{3}{*}{0.711} & \multirow{3}{*}{3} & \multirow{3}{*}{205,434} & \multirow{3}{*}{$288,975.000$} & 1 & 0.0 & 17.500 & \multirow{3}{*}{83541} \\
\hline & & & & & & 2 & -2.8 & 21.800 & \\
\hline & & & & & & 3 & 0.0 & 9.000 & \\
\hline \multirow{3}{*}{ Yellow } & \multirow{3}{*}{$\begin{array}{l}\text { Qutub Minar } \\
\text { to Huda City } \\
\text { Center }\end{array}$} & \multirow{3}{*}{0.662} & \multirow{3}{*}{4} & \multirow{3}{*}{191,230} & \multirow{3}{*}{$288,975.000$} & 1 & 0.0 & 17.500 & \multirow{3}{*}{97745} \\
\hline & & & & & & 2 & -7.2 & 21.800 & \\
\hline & & & & & & 3 & -1.0 & 9.000 & \\
\hline
\end{tabular}




\begin{tabular}{|c|c|c|c|c|c|c|c|c|c|}
\hline Line & $\begin{array}{l}\text { Delhi Metro } \\
\text { Corridors } \\
\text { [1] }\end{array}$ & $\begin{array}{l}\text { Efficiency } \\
\text { Score } \\
\text { [2] }\end{array}$ & $\begin{array}{c}\text { Rank } \\
{[3]}\end{array}$ & $\begin{array}{c}\text { Original Value } \\
\text { of Outputs } \\
{[4]}\end{array}$ & $\begin{array}{c}\text { Projected Value } \\
\text { Of Output } \\
\text { [5] }\end{array}$ & & $\begin{array}{l}\text { Value } \\
\text { puts } \\
\text { ] }\end{array}$ & $\begin{array}{c}\text { Projected Value } \\
\text { of Inputs } \\
\text { [7] }\end{array}$ & $\begin{array}{c}\text { Difference between } \\
{[4] \&[5]=} \\
{[8]}\end{array}$ \\
\hline \multirow{3}{*}{ Red } & \multirow{3}{*}{$\begin{array}{l}\text { Rithala to } \\
\text { Kanhaiya Nagar }\end{array}$} & \multirow{3}{*}{0.530} & \multirow{3}{*}{5} & \multirow{3}{*}{153,429} & \multirow{3}{*}{$289,469.000$} & 1 & 0.0 & 18.000 & \multirow{3}{*}{136040} \\
\hline & & & & & & 2 & 0.0 & 17.200 & \\
\hline & & & & & & 3 & 0.065 & 7.346 & \\
\hline \multirow{3}{*}{ Red } & \multirow{3}{*}{$\begin{array}{l}\text { Inderlok to } \\
\text { Kashmere Gate }\end{array}$} & \multirow{3}{*}{0.402} & \multirow{3}{*}{7} & \multirow{3}{*}{103,110} & \multirow{3}{*}{$256,436.868$} & 1 & 1.787 & 16.213 & \multirow{3}{*}{$153,326.868$} \\
\hline & & & & & & 2 & 0.0 & 12.600 & \\
\hline & & & & & & 3 & 0.441 & 5.559 & \\
\hline \multirow{3}{*}{ Red } & \multirow{3}{*}{$\begin{array}{l}\text { Shastri Park to } \\
\text { Dilshad Garden }\end{array}$} & \multirow{3}{*}{0.439} & \multirow{3}{*}{6} & \multirow{3}{*}{125,649} & \multirow{3}{*}{$286,200.339$} & 1 & 0.0 & 18.000 & \multirow{3}{*}{$160,551.339$} \\
\hline & & & & & & 2 & 0.0 & 15.000 & \\
\hline & & & & & & 3 & 0.459 & 6.541 & \\
\hline
\end{tabular}

FIGURE 6.

Efficiency scores of corridor performance for Delhi Metro

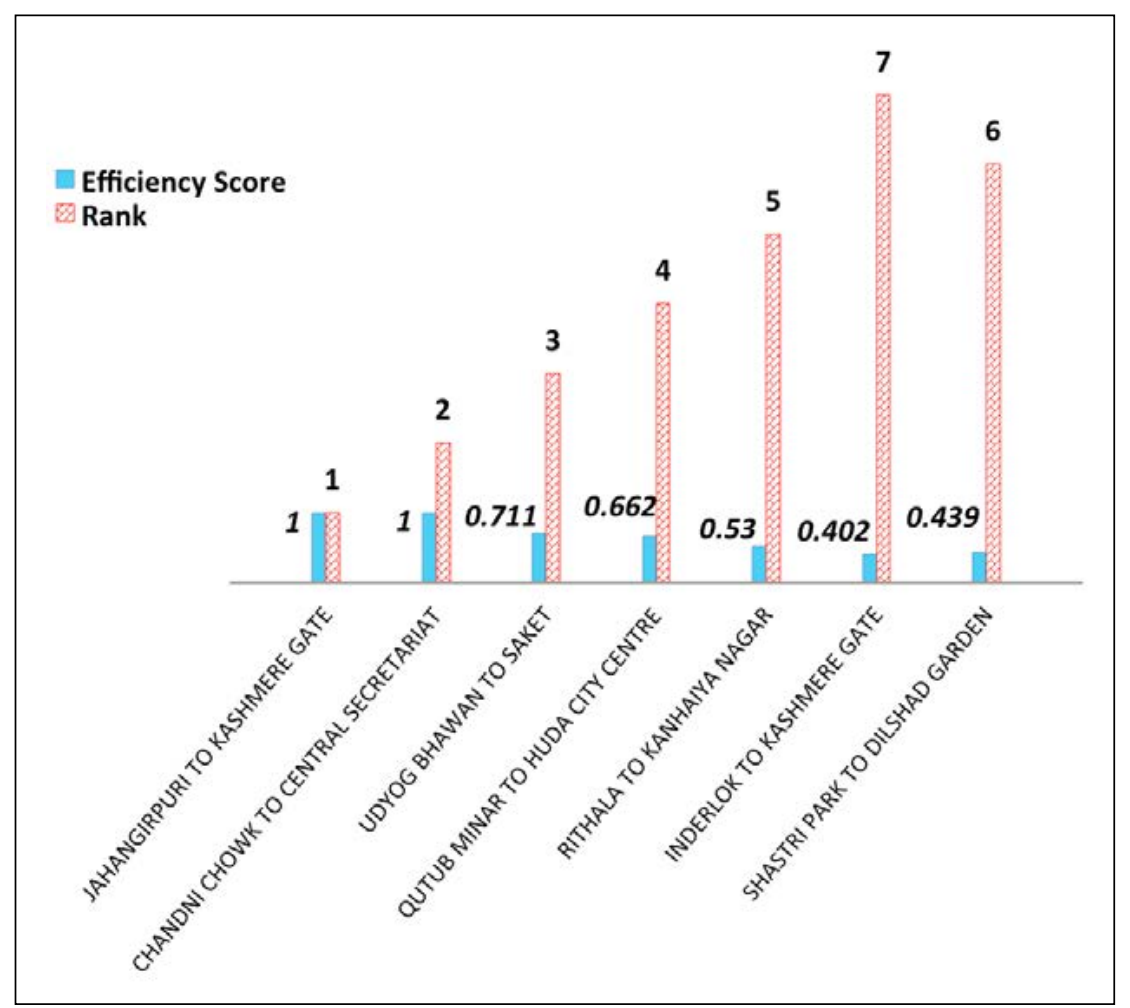


Table 5 shows the summarized observations and recommended strategies for performance enhancement of the study corridors.

TABLE 5. Strategies for Enhancement of Corridor Performance Efficiency

\begin{tabular}{|c|c|c|}
\hline Corridor Details & Observation and Interpretation & Improvement Strategies \\
\hline $\begin{array}{l}\text { Udyog Bhawan to } \\
\text { Saket }\end{array}$ & $\begin{array}{l}\text { Slack of }(-2.8) \text { in Input } 2 \text {; implies that current } \\
\text { round trip distance for this corridor is more } \\
\text { than it can effectively handle. }\end{array}$ & $\begin{array}{l}\text { - Expand operation hours. } \\
\text { - Introduce new Metro station in existing corridor. }\end{array}$ \\
\hline $\begin{array}{l}\text { Quatb Minar to } \\
\text { Huda City Center }\end{array}$ & $\begin{array}{l}\text { Slack of (-7.2) in Input } 2 \text { and 3; implies that } \\
\text { round trip distance and operating hours are } \\
\text { reasons for inefficiency. }\end{array}$ & $\begin{array}{l}\text { - Increase number of Metro stations connecting New Delhi and } \\
\text { Gurgaon. } \\
\text { - With many passengers traveling to CBD from Ghittorini, Arjangarh, } \\
\text { Chattarpur, suburbs, etc., need to increase operating times in } \\
\text { evening to make it easier to travel back home. }\end{array}$ \\
\hline $\begin{array}{l}\text { Rithala to Kanhaiya } \\
\text { Nagar \& Shastri Park } \\
\text { to Dilshad Garden }\end{array}$ & Negative slacks for Input 3. & - Need more intermediate Metro stations. \\
\hline $\begin{array}{l}\text { Inderlok to } \\
\text { Kashmere Gate }\end{array}$ & $\begin{array}{l}\text { Negative slack for operating hours input due to } \\
\text { CBD attracting huge workforce from suburban } \\
\text { areas. Also negative slack for Input } 3 \text {. }\end{array}$ & $\begin{array}{l}\text { - Increase operating hours. } \\
\text { - Need more intermediate Metro stations. }\end{array}$ \\
\hline
\end{tabular}

Overall, the line performance efficiency of all seven corridors can be summarized as the need for stations at shorter distances to increase the accessibility of commuters. Once the accessibility issue is addressed, the timing of service can be stretched, especially in the evening hours, to enhance efficiency and promote ridership. None of the outputs show a negative difference with projected values, which implies that ridership values do not indicate any overloading and have a scope that can be further improved within the available infrastructure.

\section{Operational Efficiency of Corridor}

Table 6 show the inputs and outputs for the operational efficiency of the seven line corridors of the DMRC. In this analysis, the interconnectivity ratio is taken as the performance output. Inputs 1 and 2 of this set were collected from DMRC, and Input 3 was calculated from the commuter survey data, primarily from the 1,450 respondents. Filtering of the data led to the removal of 122 responses; the remaining 1,328 were considered fit for analysis. 
TABLE 6. Inputs and Outputs for Operational Efficiency of Corridor

\begin{tabular}{|l|l|c|c|c|c|}
\hline \multicolumn{1}{|c|}{ Delhi Metro corridors } & Line & $\begin{array}{c}\text { Operating } \\
\text { Speed } \mathbf{( k m p h )}\end{array}$ & Frequency & $\begin{array}{c}\text { Access/ } \\
\text { Egress } \\
\text { Time }\end{array}$ & $\begin{array}{c}\text { Interconnectivity } \\
\text { Ratio I }\end{array}$ \\
\cline { 3 - 6 } & & Input 1 & Input 2 & Input 3 & Output \\
\hline Jahangirpuri to Kashmere Gate & Yellow & 29 & 2.9 & 21.838 & 0.301 \\
\hline Chandni Chowk to Central Secretariat & Yellow & 30 & 3 & 20.129 & 0.322 \\
\hline Udyog Bhawan to Saket & Yellow & 33 & 2.8 & 20.398 & 0.297 \\
\hline Qutub Minar to Huda City Center & Yellow & 31 & 2.8 & 22.602 & 0.269 \\
\hline Rithala to Kanhaiya Nagar & Red & 30 & 4 & 19.944 & 0.273 \\
\hline Inderlok to Kashmere Gate & Red & 32.5 & 4 & 19.500 & 0.318 \\
\hline Shastri Park to Dilshad Garden & Red & 33 & 4 & 21.056 & 0.324 \\
\hline
\end{tabular}

Figure 7 is a graphical comparison of the efficiency scores and ranks for operational efficiency.

FIGURE 7.

Operational efficiency scores and ranks of corridors

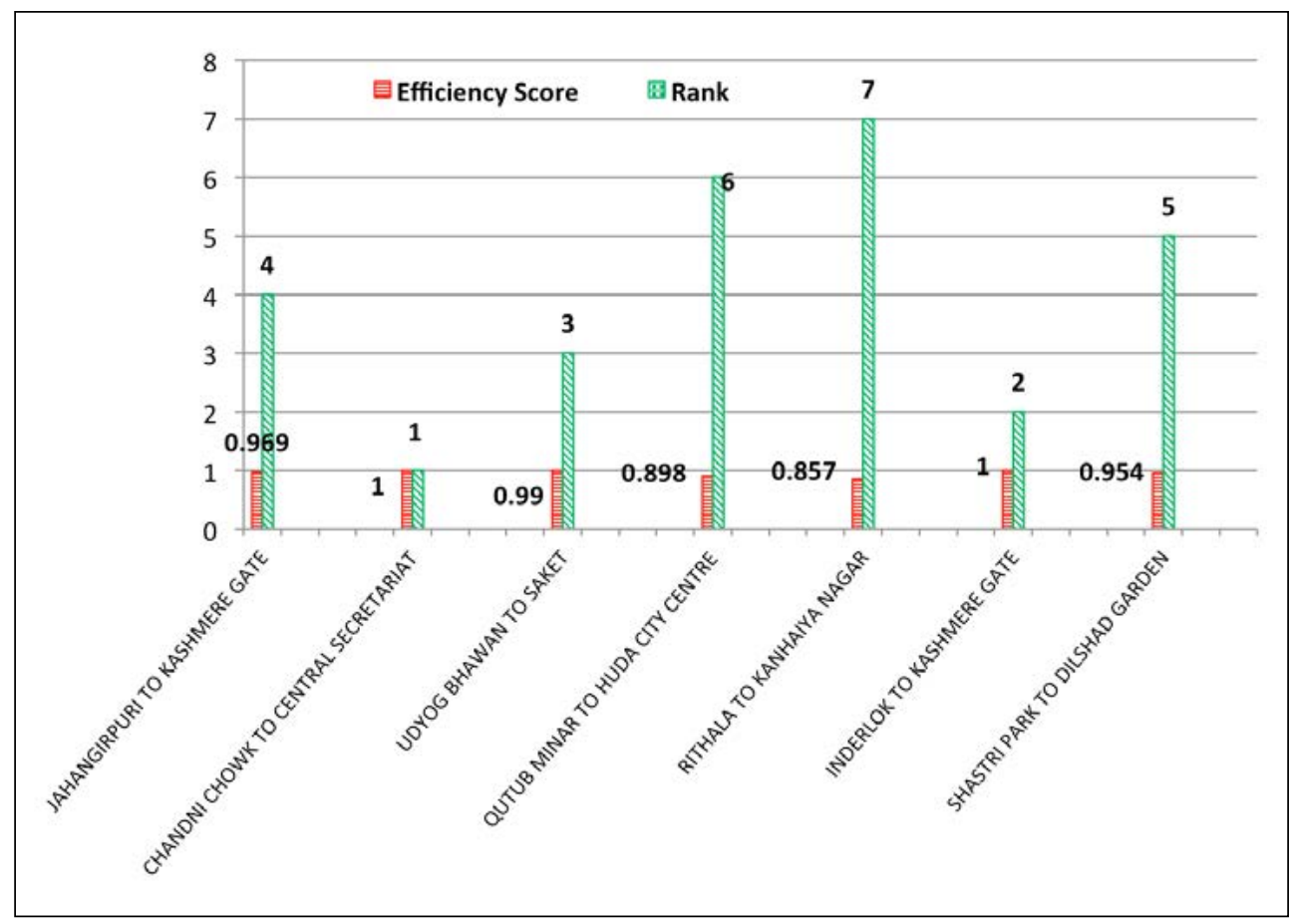

Possible solutions for enhancement and the analysis results of the operational efficiency of corridors are shown in Table 7. 
TABLE 7.

Strategies for Enhancement of Operational Efficiency of

Corridor

\begin{tabular}{|c|c|c|}
\hline Corridor Details & $\begin{array}{l}\text { Observation and } \\
\text { Interpretation }\end{array}$ & Improvement Strategies \\
\hline $\begin{array}{l}\text { Chandni Chowk to } \\
\text { Central Secretariat } \\
\text { and Inderlok to } \\
\text { Kashmere Gate }\end{array}$ & $\begin{array}{l}\text { Technically efficiency scores } \\
\text { are } 1=\text { efficient stations. }\end{array}$ & $\begin{array}{l}\text { - These two corridors are the best performing } \\
\text { among seven corridors. }\end{array}$ \\
\hline $\begin{array}{l}\text { Jahangirpuri to } \\
\text { Kashmere Gate }\end{array}$ & $\begin{array}{l}\text { Slack value of }(-2.380) \text { for } \\
\text { Input } 3 \text {. Access and egress } \\
\text { times to this station are } \\
\text { more, making this corridor } \\
\text { inefficient. }\end{array}$ & $\begin{array}{l}\text { - Extend corridor; has been proposed by DMRC } \\
\text { in Phase } 3 \text { until Badli in Yellow line beyond } \\
\text { Jahangirpuri; expected to enhance efficiency. }\end{array}$ \\
\hline $\begin{array}{l}\text { Udyog Bhawan to } \\
\text { Saket and Qutab } \\
\text { Minar to Huda City } \\
\text { Center }\end{array}$ & $\begin{array}{l}\text { Big negative slacks for } \\
\text { Inputs } 1 \text { and } 3 \text {; implies that } \\
\text { operating speed is less and } \\
\text { access/egress times are } \\
\text { more than desired. }\end{array}$ & $\begin{array}{l}\text { - Operating speed for these corridors needs to be } \\
\text { increased. } \\
\text { - Huda City Center is terminal station facing } \\
\text { access and egress problems, as passengers } \\
\text { are coming from distances far from planned } \\
\text { catchment area. } \\
\text { - Qutab Minar was terminal station extended to } \\
\text { Huda City Center. Station not well connected to } \\
\text { nearby areas; feeder or IPT connectivity needs to } \\
\text { be enhanced for these two stations areas. }\end{array}$ \\
\hline $\begin{array}{l}\text { Rithala to Kanhaiya } \\
\text { Nagar and Shastri } \\
\text { Park to Dilshad } \\
\text { Garden }\end{array}$ & $\begin{array}{l}\text { Slacks of }(-0.940) \text { and } \\
(-0.347) \text { for Input } 2= \\
\text { frequency of arrival of } \\
\text { consecutive Metro trains in } \\
\text { these corridors is less. }\end{array}$ & $\begin{array}{l}\text { Frequency for these corridors can be increased. } \\
\text { Increase in number of coaches will increase } \\
\text { capacity and may increase efficiency. }\end{array}$ \\
\hline
\end{tabular}

The operational efficiency of the seven line corridors reveals that speed and frequency of the Delhi Metro need to be augmented. Also, Metro extension phases related to the growing city size need to be planned in advance to counter the problem of excessive access and egress distances at terminal stations.

\section{Spatial Efficiency of Corridor}

This section evaluates efficiency on a spatial basis. Inputs 1, 2, and 4 were calculated from the 1,328 responses. Input 3 was observed at various stations during the survey collection visits and recorded separately. Table 8 shows the data for the spatial efficiencies of the seven corridors. 
TABLE 8. Inputs and Outputs for Spatial Efficiency of Corridor

\begin{tabular}{|l|c|c|c|c|c|c|}
\hline \multirow{2}{*}{ Delhi Metro Corridors } & \multirow{2}{*}{ Line } & $\begin{array}{c}\text { Total } \\
\text { Travel } \\
\text { Time }\end{array}$ & $\begin{array}{c}\text { Customer } \\
\text { Perception } \\
\text { on Access/ } \\
\text { Egress }\end{array}$ & $\begin{array}{c}\text { Availability } \\
\text { of Feeder } \\
\text { in Area }\end{array}$ & $\begin{array}{c}\text { Travel } \\
\text { Time } \\
\text { Ratio }\end{array}$ & $\begin{array}{c}\text { Interconnectivity } \\
\text { Convenience } \text { c }_{c}\end{array}$ \\
\cline { 3 - 7 } & Input 1 & Input 2 & Input 3 & Input 4 & Output \\
\hline Jahangirpuri to Kashmere Gate & Yellow & 72.493 & 9.045 & 0.111 & 2.085 & 0.663 \\
\hline Chandni Chowk to Central Secretariat & Yellow & 62.600 & 8.508 & 0.001 & 2.213 & 0.722 \\
\hline Udyog Bhawan to Saket & Yellow & 68.644 & 8.694 & 0.333 & 2.278 & 0.628 \\
\hline Qutub Minar to Huda City Center & Yellow & 83.884 & 8.780 & 0.001 & 2.501 & 0.514 \\
\hline Rithala to Kanhaiya Nagar & Red & 72.944 & 7.827 & 0.375 & 2.552 & 0.570 \\
\hline Inderlok to Kashmere Gate & Red & 61.297 & 8.035 & 0.001 & 2.087 & 0.782 \\
\hline Shastri Park to Dilshad Garden & Red & 65.000 & 8.459 & 0.143 & 2.094 & 0.777 \\
\hline
\end{tabular}

Figure 8 is a graphical comparison of the efficiency scores and ranks for spatial efficiency, and Table 9 includes remarks on the analysis of the spatial efficiency of corridors.

FIGURE 8.

Spatial efficiency scores and ranks of corridors

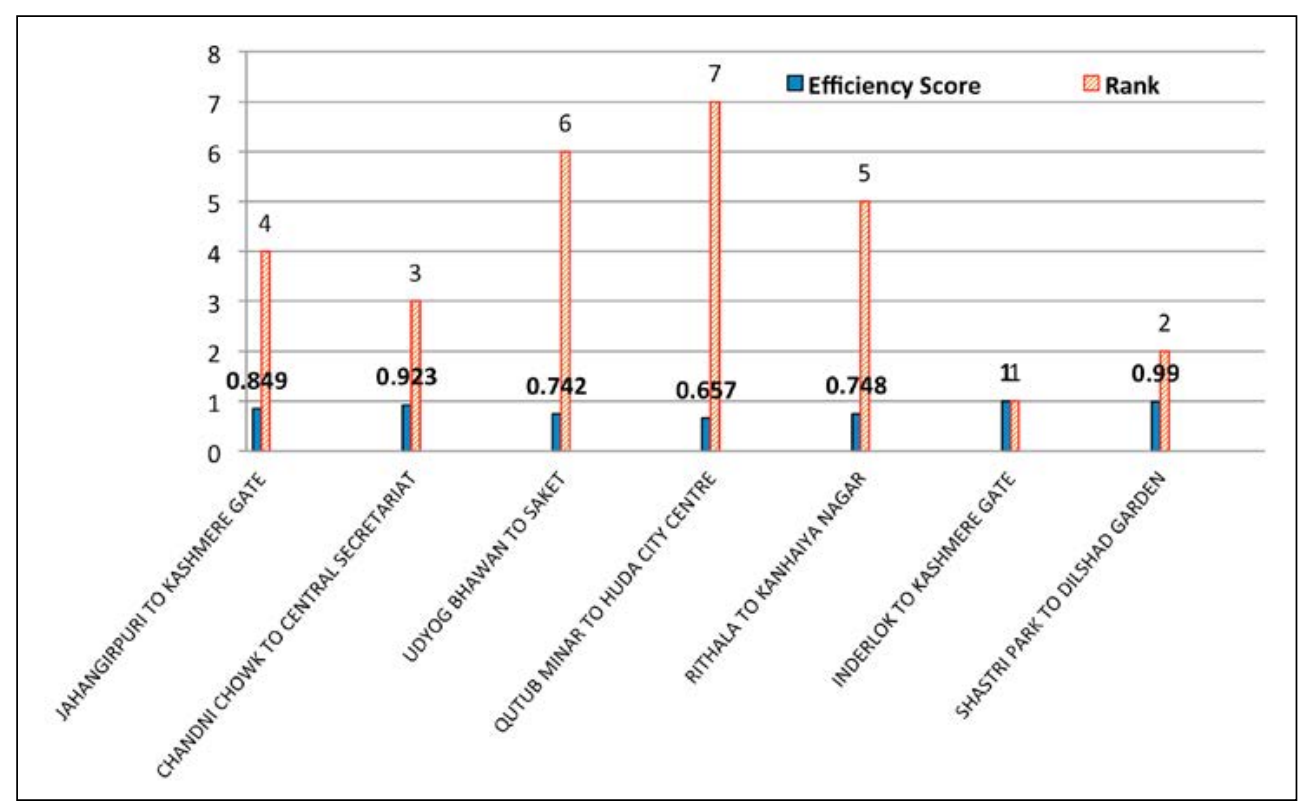


TABLE 9. Strategies for Enhancement of Spatial Efficiency of Corridor

\begin{tabular}{|c|c|c|}
\hline Corridor Details & Observation and Interpretation & Improvement Strategies \\
\hline $\begin{array}{l}\text { Jahangirpuri to } \\
\text { Kashmere Gate } \\
\text { and Shastri Park to } \\
\text { Dilshad Garden }\end{array}$ & $\begin{array}{l}\text { Negative slacks for Inputs } 1,2,3 \text {. Big } \\
\text { slack value for } \\
(-11.255) \text { for total travel time; indicates } \\
\text { that total travel time is more than } \\
\text { desirable on these corridors. }\end{array}$ & $\begin{array}{l}\text { - Since total travel time is a function of speed and corridor } \\
\text { distance, these can be enhanced in this case. } \\
\text { - Additional feeder connectivity required to increase } \\
\text { interconnectivity convenience for passengers. } \\
\text { - Jahangirpuri (terminal station) has poor access/egress facilities, } \\
\text { which increases total travel time on this corridor. }\end{array}$ \\
\hline $\begin{array}{l}\text { Chandni Chowk to } \\
\text { Central Secretariat } \\
\text { and Qutab Minar } \\
\text { to Huda City } \\
\text { Center }\end{array}$ & $\begin{array}{l}\text { Negative slacks for Inputs 1,2, } 4 \text {; } \\
\text { suggests that total travel time, } \\
\text { customer perception of access and } \\
\text { egress, and travel time ratio of these } \\
\text { corridors are problem areas. Big slack } \\
\text { (-22.587) in Qutab Minar to Huda } \\
\text { City Center corridor, indicates bigger } \\
\text { portion of access and egress in total } \\
\text { travel time. }\end{array}$ & $\begin{array}{l}\text { - Huda City Center (terminal station) contributes to access/egress } \\
\text { times more than IVTT, which eventually affects travel time ratio. } \\
\text { More temporal delay discourages passengers to use public transit. } \\
\text { Good integration from near and far areas required to increase } \\
\text { proximal connectivity to terminal stations. }\end{array}$ \\
\hline $\begin{array}{l}\text { Udyog Bhawan to } \\
\text { saket \& Rithala to } \\
\text { Kanhaiya Nagar }\end{array}$ & $\begin{array}{l}\text { Total travel time, travel time ratio, } \\
\text { and availability of feeder in area are } \\
\text { problem elements. }\end{array}$ & $\begin{array}{l}\text { - Rithala (terminal station) contributes to increased total travel } \\
\text { time. } \\
\text { - Customer perception on access and egress good, indicates that } \\
\text { IVTT hampers perception instead of OVTT. This means that } \\
\text { speed and frequency of corridor needs to be enhanced. }\end{array}$ \\
\hline $\begin{array}{l}\text { Shastri Park to } \\
\text { Dilashad Garden }\end{array}$ & Slack values for Inputs 1,2, 3 & $\begin{array}{l}\text { - Dilshad Garden (terminal station) requires feeder service } \\
\text { augmentation. }\end{array}$ \\
\hline
\end{tabular}

Spatial line efficiency results indicate that terminal stations have a common issue of increased access/egress time and, therefore, reduced interconnectivity convenience. The output projected values reveal a scope for improvement in the interconnectivity convenience of commuters. The ease of access/egress facilities and time savings in the intermodal or multimodal transfer process of the Metro terminals should be considered for enhancement to make these corridors more efficient spatially.

\section{Proximal Efficiency}

There are 34 Metro stations on the Yellow line and 21 on the Red line, with one common station, Kashmere Gate. Proximal efficiency compared the different stations for ease of accessibility that each of these stations provides in its respective catchment areas. The output parameter is the sum of total time taken for accessing and egressing the line haul mode. Inputs 1, 2, and 3 were calculated from the data acquired from the primary commuter travel time survey.

The common station Kashmere Gate is also an interstate bus transfer terminal (ISBT) and has been developed as a multimodal interchange hub by DMRC and DIMTS (Delhi Integrated Multimodal Transit System Limited). Kashmere Gate, along with G.T.B. Nagar and Ghittorini on the Yellow line and Pulbangash on the Red line, are bestpractice stations in terms of proximal connectivity for commuters. Figure 9 shows the comparison of efficiency scores and ranks of proximal efficiency. 


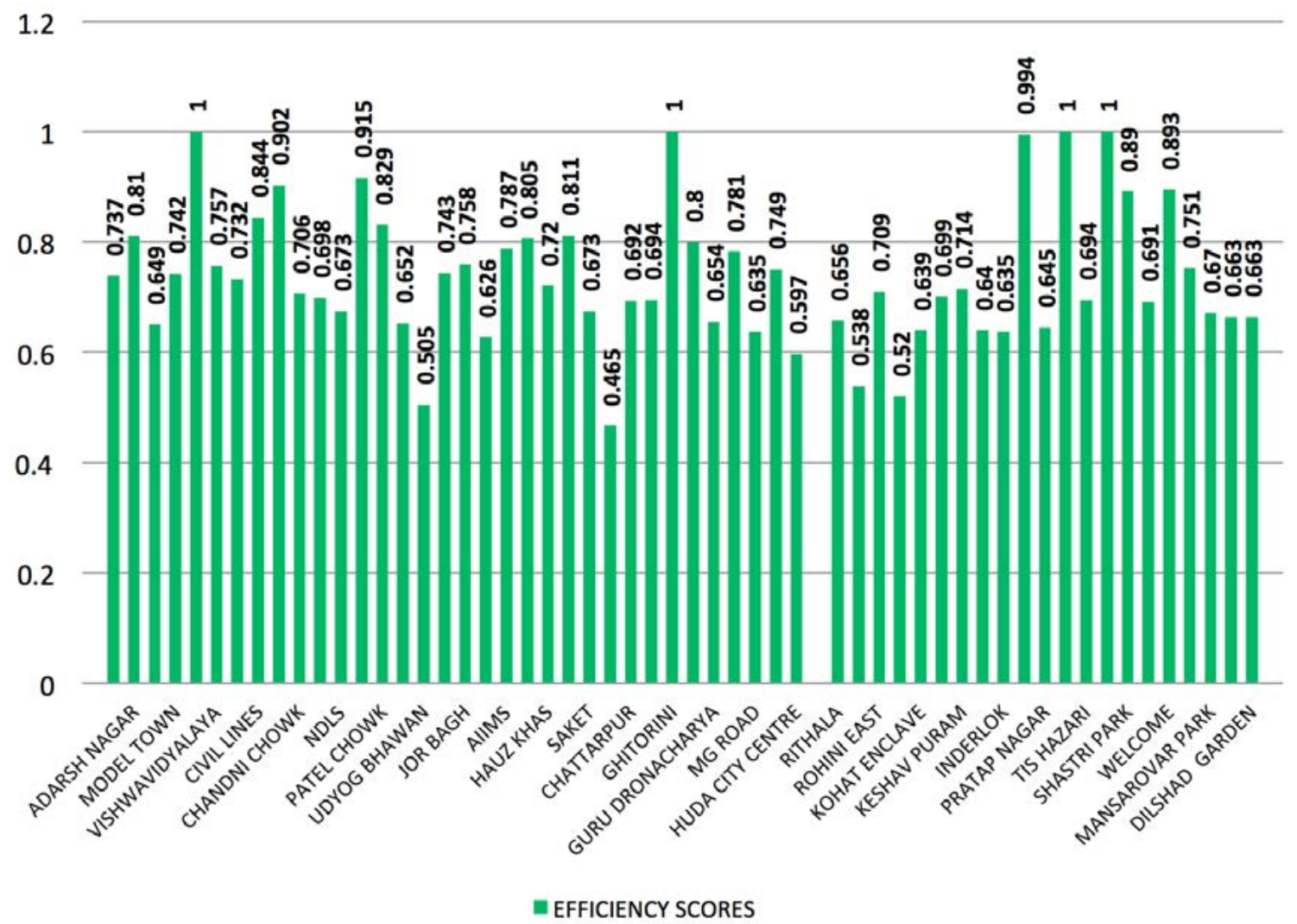

FIGURE 9. Proximal efficiency scores of corridors

Strategies to improve the proximal efficiency of stations are presented in Table 10.

TABLE 10. Strategies for Enhancement of Proximal Efficiency of Corridor

\begin{tabular}{|c|c|c|}
\hline Station Details & $\begin{array}{l}\text { Observation and } \\
\text { Interpretation }\end{array}$ & Improvement Strategies \\
\hline $\begin{array}{l}\text { Yellow Line: Chawri Bazaar, } \\
\text { NDLS, Central Secretariat, } \\
\text { INA, Saket, Chattarpur, } \\
\text { Sultanpur, Guru Dronacharya, } \\
\text { M. G. Road } \\
\text { Red Line: Rithala, Kohat } \\
\text { Enclave, Netaji Subhash Place, } \\
\text { Kanhaiya Nagar, Inderlok, } \\
\text { Pratap Nagar, Tis Hazari, } \\
\text { Seelampur, ManasarovarPark, } \\
\text { Jhilmil, Dilshad Garden }\end{array}$ & $\begin{array}{l}\text { Waiting times } \\
\text { on platform and } \\
\text { transfer time } \\
\text { are longer. IVTT } \\
\text { is a reason for } \\
\text { inefficiency. }\end{array}$ & $\begin{array}{l}\text { - For heavily residential areas, station area design needs to be improved to reduce } \\
\text { walking in transfer areas and increase frequency and speed to reduce IVTT. } \\
\text { - For commercial zones, footfall in peak hours is more, so transfer procedure needs to be } \\
\text { augmented, which may require additional safety check counters and turnstiles to cater } \\
\text { to large crowds. } \\
\text { - For interchange stations, transfer area reduction between two modes can help } \\
\text { efficiency. } \\
\text { - Additional baggage check counter for luggage carried by intercity travelers can save } \\
\text { time in security check process. Travelators could be provided to facilitate interchange } \\
\text { process between modes. } \\
\text { - Medium- to high-density mixed-use suburban areas may increase patronage if transfer } \\
\text { facilities in peak hours are augmented. } \\
\text { - In busy CBD areas with major work/education destinations, number of coaches in peak } \\
\text { hours needs to be increased to cater to larger number of passengers. }\end{array}$ \\
\hline $\begin{array}{l}\text { Udyog Bhawan, Pitampura, } \\
\text { Huda City Centre, Qutab } \\
\text { Minar, Rohini West }\end{array}$ & $\begin{array}{l}\text { Very poor } \\
\text { performance. }\end{array}$ & - Availability of feeder and IPT modes needs to be promoted for these stations. \\
\hline
\end{tabular}




\section{Information and Safety Efficiency}

Customer perception in the context of the information and security infrastructure available at the Metro stations was used as input in this section. Further, an overall customer perception score was calculated using the primary data collected in the customer perception questionnaire. The customer perception score was used as the output in this set. Figure 10 is a graphical comparison of efficiency scores and ranks for information and safety efficiency.

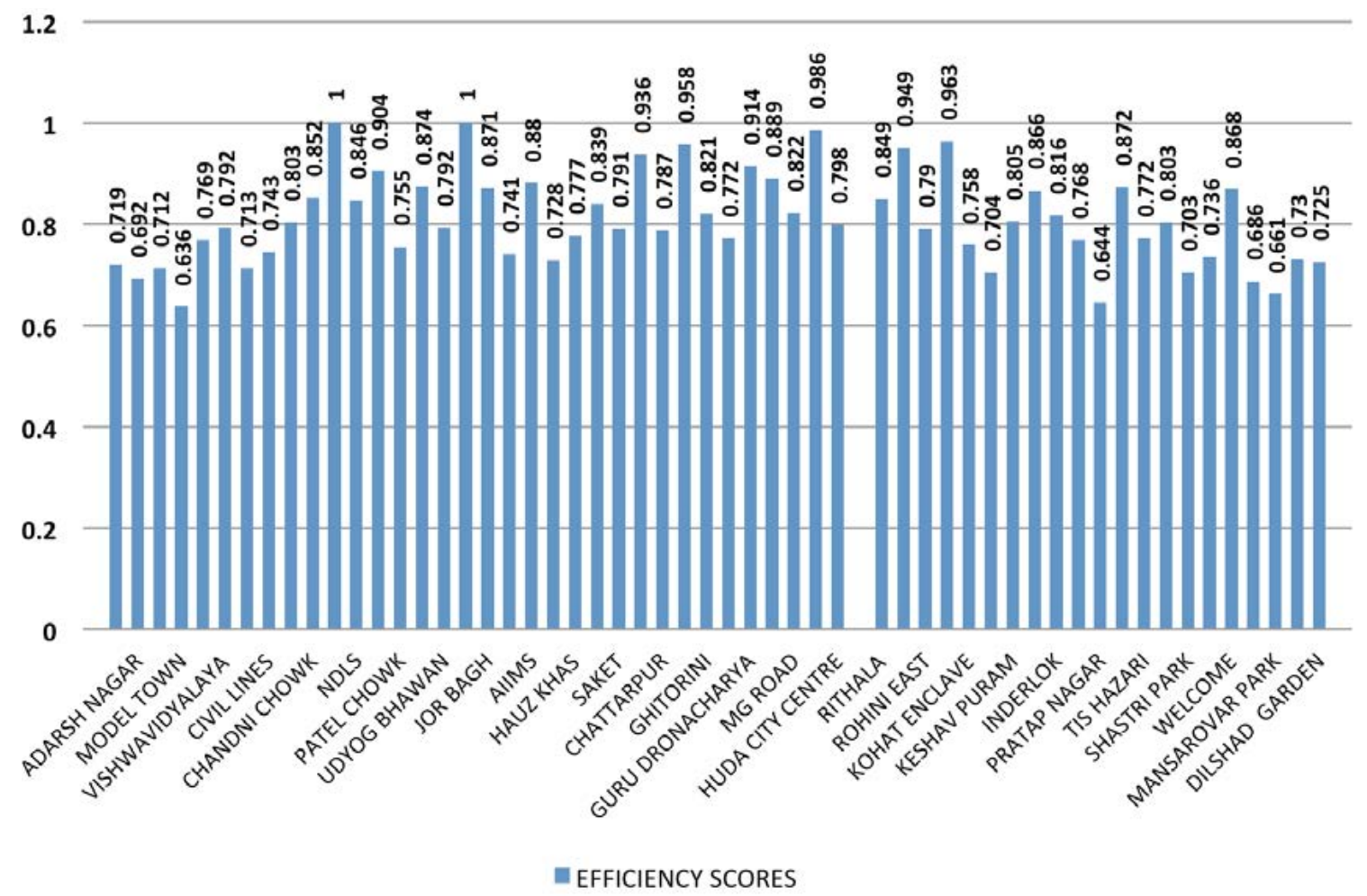

FIGURE 10. Information and security scores of corridors

This set covered the safety and information aspect of travel in a multimodal transit environment. Results show that the efficiency of the 54 stations related to safety and information is better and that the station areas are comparatively considered safer according to customer perception. Also, an ample number of billboards and station premises signage ensures that commuters are well informed. The stations exhibiting the best practices in this segment were Race Course and Chawri Bazaar of the Yellow line; the stations that require improvement are Mansarovar Park, Shahadra, Pratap Nagar, Adarsh Nagar and Model Town. 


\section{Multimodal Efficiency}

In the multimodal efficiency calculation, the overall contribution of the seven line haul corridors individually was considered. The data for the entire trip of an individual (in these cases, multimodal trips) was used for evaluation. Table 11 shows the objective data of this set. The performance parameter considered was the level of service of these corridors calculated from the primary data. The inputs were calculated from the responses of commuter travel time data. Figure 11 is a graphical comparison of efficiency scores and ranks for multimodal efficiency. Strategies for improving multimodal efficiency are shown in Table 12.

TABLE 11.

Inputs and Outputs for Multimodal Efficiency

\begin{tabular}{|l|c|c|c|c|c|}
\hline \multicolumn{1}{|c|}{ Delhi Metro Corridors } & Line & $\begin{array}{c}\text { Passenger } \\
\text { Waiting } \\
\text { Index (PWI) }\end{array}$ & $\begin{array}{c}\text { Service Time } \\
\text { Ratio } \\
\text { (STR) }\end{array}$ & $\begin{array}{c}\text { Interconnectivity } \\
\text { Ratio } \\
\left(I_{R}\right)\end{array}$ & $\begin{array}{c}\text { Level of } \\
\text { Service } \\
\text { (LOS) }\end{array}$ \\
\cline { 3 - 6 } & Input 1 & Input 2 & Input 3 & Output \\
\hline Jahangirpuri to Kashmere Gate & Yellow & 2.011 & 0.222 & 0.301 & 0.714 \\
\hline Chandni Chowk to Central Secretariat & Yellow & 1.829 & 0.244 & 0.322 & 0.699 \\
\hline Udyog Bhawan to Saket & Yellow & 2.062 & 0.222 & 0.297 & 0.645 \\
\hline Qutub Minar to Huda City Center & Yellow & 2.179 & 0.191 & 0.269 & 0.545 \\
\hline Rithala to Kanhaiya Nagar & Red & 1.713 & 0.239 & 0.273 & 0.587 \\
\hline Inderlok to Kashmere Gate & Red & 1.601 & 0.269 & 0.318 & 0.796 \\
\hline Shastri Park to Dilshad Garden & Red & 1.675 & 0.260 & 0.324 & 0.775 \\
\hline
\end{tabular}

FIGURE 11.

Multimodal efficiency scores and ranks of corridors

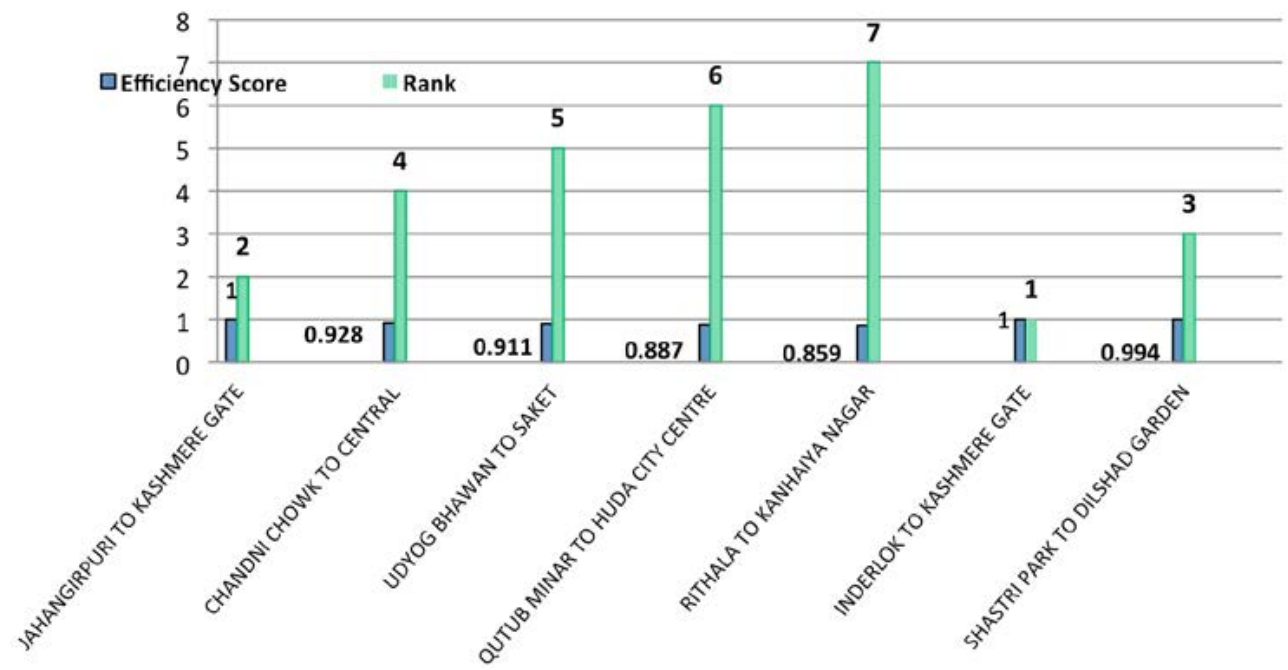


TABLE 12.

Strategies for Improving Multimodal Efficiency of

Corridors

\begin{tabular}{|l|l|l|}
\hline \multicolumn{1}{|c|}{ Corridor Details } & \multicolumn{1}{|c|}{$\begin{array}{c}\text { Observation and } \\
\text { Interpretation }\end{array}$} & \multicolumn{1}{c|}{ Improvement Strategies } \\
\hline $\begin{array}{l}\text { Jahangirpuri to } \\
\text { Kashmere Gate } \\
\text { Kashmerlok to }\end{array}$ & Technically efficient. & $\begin{array}{l}\text { Better performance in context to multimodal } \\
\text { integration. }\end{array}$ \\
\hline $\begin{array}{l}\text { Shastri Park to } \\
\text { Dllshad Garden \& } \\
\text { Chandni Chowk to } \\
\text { Central Secretariat }\end{array}$ & $\begin{array}{l}\text { Inefficiency linked to } \\
I_{R} \text { input. }\end{array}$ & $\begin{array}{l}\text { Affects overall LOS; is a measure of proximity so } \\
\text { improvement in access/egress facilities should } \\
\text { improve OVTT values. }\end{array}$ \\
\hline $\begin{array}{l}\text { Udyog Bhawan to } \\
\text { Saket }\end{array}$ & PWI more than desired. & $\begin{array}{l}\text { Demand supply gap in capacity for transfer and travel } \\
\text { need to be addressed. }\end{array}$ \\
\hline $\begin{array}{l}\text { Rithal to Kanhaiya } \\
\text { Nagar }\end{array}$ & $\begin{array}{l}\text { Negative slacks for } \\
\text { Inputs 1 \& 2. Waiting } \\
\text { time and service time } \\
\text { ratio are weak links. }\end{array}$ & $\begin{array}{l}\text { Terminal station proximal connectivity needs to be } \\
\text { addressed at Rithala. Phase 3: no extension proposed } \\
\text { beyond Rithala on Red line. }\end{array}$ \\
\hline $\begin{array}{l}\text { Qutab Minar to } \\
\text { HudaCity Center }\end{array}$ & $\begin{array}{l}\text { PWI more than desired. } \\
I_{R} \text { value shows negative } \\
\text { slack. }\end{array}$ & $\begin{array}{l}\text { Feeder and IPT connectivity need to be strengthened. } \\
\text { Wait times are more due to terminal stations at both } \\
\text { ends; needs better proximal connectivity. }\end{array}$ \\
\hline
\end{tabular}

Here again, none of the outputs portray a negative slack with their projected values, which indicates that to make the Yellow and Red lines more multimodal-friendly and enhance the efficacy of multimodality, much work needs to be done. The output values show a tremendous scope for improvement in this set.

The comparative summary of various input and output evaluation sets at the corridor level are illustrated in Figure 12. As can be seen, of the seven corridors compared, three corridors need significant improvement in all aspects. 
FIGURE 12.

Summary of corridor level efficiency scores
- Corridor Performance Efficiency Score

W Spatial Efficiency Score

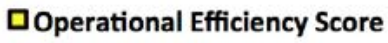

$\square$ Multimodal Efficiency Score

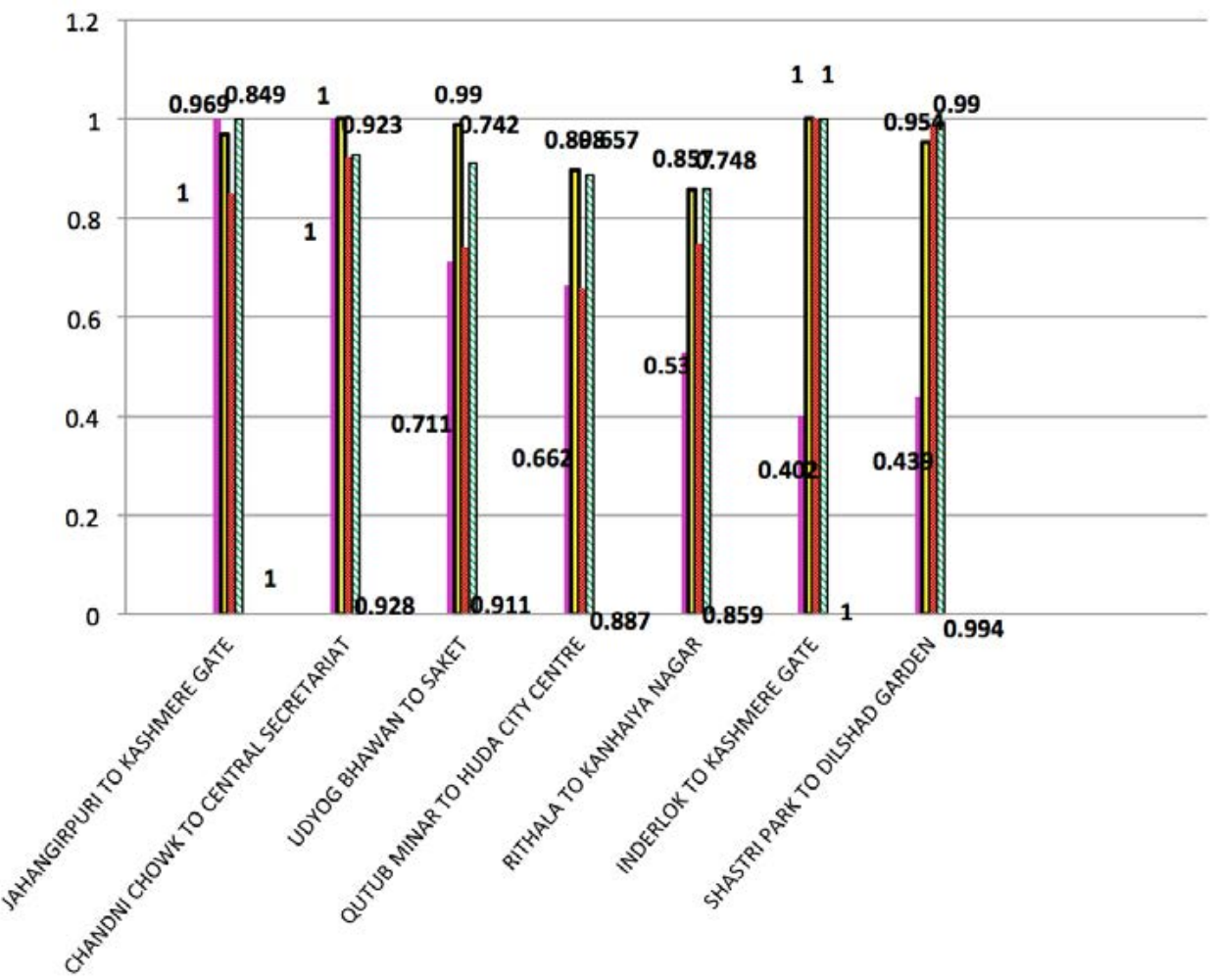

\section{Conclusion}

The results of the efficiency analysis carried out on operational, spatial, proximal, and corridor performance and information, security, and overall multimodal efficiency attributes of the major line haul mode of Delhi revealed collective and individual characteristics of the entire system as well as gaps in performance. Each station has its own set of dynamic attributes and, for each station, a different approach is needed to enhance its contribution towards the multimodal fabric of the system. The following conclusions were drawn from the present study.

1. DEA is an effective technique to compare the relative efficiencies of DMUs using a multitude of inputs and outputs to assess a multimodal public transit system.

2. DEA analysis not only provides technical efficiencies after comparing DMUs but also provides target values for inputs and outputs of all other DMUs to achieve the efficiency equivalent of the best-performing DMU. Also, DEA analysis provides specific slack values, which makes it easy to determine the weak and strong links of the DMUs in the system.

3. Among the corridors, Jahangirpuri to Kashmere Gate on the Yellow line and Inderlok to Kashmere Gate on the Red line emerged as the best-performing corridors in the relative efficiency analysis. Qutab Minar to Huda City Center was the worst-performing corridor. 
4. Among individual stations, efficient stations include Kashmere Gate, which is common to both lines; on the Yellow Line, G.T.B. Nagar, Rajiv Chowk, Malviya Nagar, and Ghitorini emerged as the better-performing stations; and on the Red line, Pulbangash and Welcome Station performed better.

5. The corridors that have terminal stations indicate several access/egress distance issues. This is mainly because people from areas out of catchment of the terminal stations come from distant areas to use Metro services. This calls for an extension of lines or very strong and efficient feeder connectivity to the areas beyond the last station for better interconnectivity.

6. The stations in Central Delhi and the CBD areas should concentrate on reducing passenger waiting times and transfer times. This can be done by using travelators on interchange stations, introducing parking areas that are internally connected with the stations, installing turnstiles to reduce queue times, etc.

7. The suburban areas from which large numbers of commuters move to the $\mathrm{CBD}$ or to prominent work and education centers are less efficient in terms of operational hours, especially at night, resulting in longer transfer time delays. Passengers could travel more from the suburbs if timing was extended at night.

8. Access and egress legs emerged as the weakest links of all the corridors and individual stations in the study. This is due to poor connectivity and poor scheduling of connecting modes. Organized routes and enhancement of feeder connectivity are required on a large scale along the Yellow and Red line routes of Delhi Metro.

9. Transfer areas could be designed or infrastructurally augmented to promote fast transfers for a large number of passengers simultaneously. More staff could be deployed for peak hours, or more parking can be provided for stations with larger footfalls.

\section{References}

Adib, K., and R. Wang. 2010. "Measuring Multimodal Transport Level of Service." University of California Transportation Center, Berkeley.

Atkins, S. T. 1990. "Personal Security as a Transport Issue, A State of the Art Review." Transportation Reviews, 10(2): 111-125.

Barnum, D. T., Sue McNeil, and Jonathon Hart. 2007. "Comparing the Efficiency of Public Transport Subunits using Data Envelopment Analysis." Journal of Public Transportation, 10 (2): 1-16.

Census of India. 2011. Population of Delhi in 2011. http://censusindia.gov.in/.

Charnes, A., W. W. Cooper, and E. Rhodes. 1978. "Measuring the Efficiency of Decision Making Units." European Journal of Operational Research, 2: 429-444. 
Chowdhury, S., and A. Ceder. 2013. "Definition of Planned and Unplanned Transfer of Public Transport Service and User Decisions to Use Routes With Transfers." Journal of Public Transportation, 16(2): 1-20.

Cooper, W. W., L. M. Seiford, and Tone Kaoru. 2006. Introduction to Data Envelopment Analysis and Its Uses. New York: Springer Publications.

Diana, M. 2012. "Measuring the Satisfaction of Multimodal Travelers for Local Transit Services in Different Urban Contexts." Transportation Research Part A, 46(1): 1-11.

Eboli, L., and G. Mazzulla, 2009. "A New Customer Satisfaction Index for Evaluating Transit Service Quality." Journal of Public Transportation, 12(3): 21-37.

Eluru, N., and V. Chakour. 2012. "Travel Mode Choice AND Transit Route Choice Behavior in Montreal: Insights from McGill University Members Commute Patterns." Public Transport, 4: 129-149.

Epstein, M. K., and J. C. Henderson. 1989. “Data Envelopment Analysis for Managerial Control and Diagnosis." Decision Science, (20): 90-119.

Guo Z, and N. H. M. Wilson. 2011. "Assessing the Cost of Transfer Inconvenience in Public Transport Systems: A Case Study of London Underground." Transportation Research, 4(5): 91-104.

Hidalgo, D. 2009. “Citywide Transit Integration in a Large City: The Interligado System of Sao Paulo, Brazil." Transportation Research Record, 2114: 19-27.

Karlaftis, M. G. 2003. "Investigating Transit Production and Performance: A Programming Approach." Transportation Research A, 37(3): 225-240.

Krygsman, S., and M. Djist. 2001. "Multimodal trips in Netherlands-Microlevel Individual Attributes and Residential Context." Transportation Research Record, 1753: 11-19.

Krygsman, S., M. Dijst, and T. Arentze. 2004. "Multimodal Public Transport: An Analysis of Travel Time Elements and the Interconnectivity Ratio." Transport Policy,11: 265275.

Kumar, P., S. Y. Kulkarni, and M. Parida. 2011. "Security Perceptions of Delhi Commuters at Metro-Bus Interchange in Multimodal Perspective." Journal of Transport Security, 4: 295-307.

Lao, Y., and L. Lin. 2009. "Performance Evaluation of Bus Lines with Data Envelopment Analysis and Geographic Information Systems." Computers, Environment and Urban Systems, 33: 247-255.

Markovits-Somogyi, R., and Z. Bokor. 2014. "Assessing the Logistics Efficiency of European Countries by using DEA-PC Methodology." Transport, 29(2): 137-145.

Markovits-Somogyi, R. 2011. "Measuring Efficiency In Transport: The State of the Art of Applying Data Envelopment Anaysis." Transport, 26(1): 11-19.

Maxwell, R. R. 2003. "Converting a Large Region to a Multimodal Pulsed-Hub Public Transport Network." Transportation Research Record, 1835: 128-136. 
Saxena, P., and R. R. Saxena. 2010. "Measuring Efficiencies in Indian Public Road Transit: A Data Envelopment Analysis Approach." Operation Research, 47(3): 195-204.

Sharfuddin, J. S., and A. M. Khan. 2000. "Factor Analysis for the Study of Determinants of Public Transit Ridership." Journal of Public Transportation, 3(3): 1-17.

Singh, S. K. 2005. "Review of Urban Transportation in India." Journal of Public Transportation, 8(1):79-97.

Smart, M., M. A. Miller, and B. D. Taylor. 2009. "Transit Stops and Stations: Transit Manager Perspectives on Evaluating Performance." Journal of Public Transportation, 12(1): 59-77.

Spring, C. 2010. “Determinants of Passenger Transfer Waiting Time at Multi-Modal Connecting Stations." Transportation Research Part E, 46: 404-413.

Sun, L., J. Rong, F. Ren, and L. Yao. 2007. "Evaluation of Passenger Transfer Efficiency of an Urban Public Transportation Terminal." Proceedings of IEEE Intelligent Transportation Systems Conference, Seattle, WA.

Van Oort, N., and R. van Nes. 2009. "Regularity Analysis for Optimizing Urban Transit Network Design." Public Transport, 1: 155-168.

Vuchic, V. R., and S. Kikuchi. 1974. "Design of Outlying Rapid Transit Station Areas." Transportation Research Record, 505: 1-12.

Wei, Z., P. Zhao, and A. Shulin. 2012. "Efficiency Evaluation of Beijing Intelligent Traffic Management System Based on Super-DEA." Journal of Transportation Systems Engineering and Information Technology, 12(3):,19-23.

\section{About the Authors}

MANSHA SWAMI (mansha.swami@gmail.com) is a Civil Engineering graduate with post-graduate studies in Transportation Engineering and Planning. She is pursuing doctoral research at the Indian Institute of Technology Roorkee. Her research interests include material design for highways, traffic engineering, and urban public transportation planning.

DR. Manoranjan Parida (mparida@gmail.com) is a Professor in the Civil Engineering Department and Dean of Sponsored Research \& Industrial Consultancy at IIT Roorkee. Among his areas of research specialization are urban transportation planning and traffic safety. He has contributed more than 330 research papers/articles to international journals and conference proceedings and has published chapters in two books. 